ENTREPRENEURSHIP AND SUSTAINABILITY ISSUES

ISSN 2345-0282 (online) http://jssidoi.org/jesi/

2020 Volume 8 Number 2 (December)

http://doi.org/10.9770/jesi.2020.8.2(69)
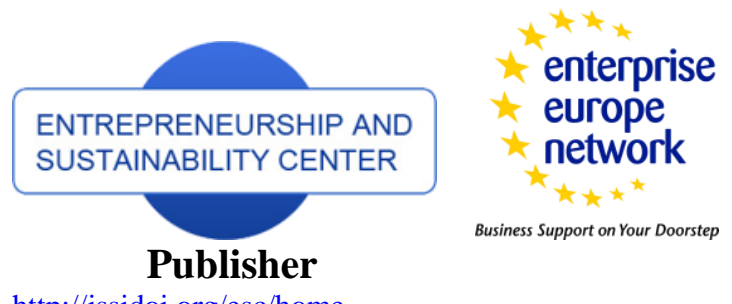

CASPA Scopus

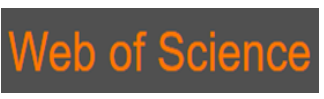

http://jssidoi.org/esc/home

\title{
THE IMPACT OF PUBLIC-PRIVATE PARTNERSHIP ON LABOR MOBILITY AND EMPLOYMENT PROMOTION
}

\author{
Raikhan Nuranova ${ }^{1}$, Maira Ryskulova ${ }^{2}$, Kulyash Aidarkhanova ${ }^{3}$, Nurgul Baigelova ${ }^{4}$ \\ 1,2,4 Narxoz University, Almaty, Kazakhstan \\ ${ }^{3}$ Al-Farabi Kazakh National University, Almaty, Kazakhstan \\ E-mails: ${ }^{1}$ raikhan.nuranova@narxoz.kz; ${ }^{2}$ maira.ryskulova@narxoz.kz; ${ }^{3}$ aidarkhanova_k@mail.ru;
}

Received 16 July 2019; accepted 11 October 2020; published 30 December 2020

\begin{abstract}
In conditions of a budget deficit, an urgent task facing the state is the development of new instruments that allow replacing budget investments in the creation and modernization of infrastructure with private investments and at the same time optimizing financial costs for these purposes. The priority direction of the investment policy of the regions and the country as a whole is the implementation of socially significant projects using public-private partnership mechanisms, the task of which is to maximize the potential of business for the implementation of the tasks for which the state bears responsibility. The purpose of the study of this article is to analyze the indicators of public-private partnerships in relation to the development of labor mobility, which make it possible to judge the effectiveness of the state policy in the field of employment regulation. The current situation in the labor market is always in the focus of attention of the state, business and society as a whole, affecting both on the economic development of the country, social policy, competitiveness of enterprises, and on the well-being of the individual.
\end{abstract}

Keywords: public-private partnership (PPP); economically active population (EAP); labor market; labor mobility; workforce; qualified workforce

Reference to this paper should be made as follows: Nuranova, R., Ryskulova, M., Aidarkhanova, K., Baigelova, N. 2020. The impact of public-private partnership on labor mobility and employment promotion. Entrepreneurship and Sustainability Issues, 8(2), 1158-1176. http://doi.org/10.9770/jesi.2020.8.2(69)

JEL Classifications: J45, J48

\section{Introduction}

Public-private partnership is a contractual relationship between government agencies and private business, which implies mutually beneficial coordinated cooperation between the parties in the implementation of projects of social and state importance, and financial risks, costs and results are distributed in proportions, in accordance with the provisions of a legally binding agreement. 


\section{ENTREPRENEURSHIP AND SUSTAINABILITY ISSUES}

ISSN 2345-0282 (online) http://jssidoi.org/jesi/

2020 Volume 8 Number 2 (December)

http://doi.org/10.9770/jesi.2020.8.2(69)

Make your research more visible, join the Twitter account of ENTREPRENEURSHIP AND SUSTAINABILITY ISSUES: @Entrepr69728810

Public-private partnership has established itself as a successful tool for interaction between business and the state. A lot of work is being done in Kazakhstan for the qualitative growth and development of the PPP mechanism. The most active partnership between the state and business is developing in the field of education.

The current stage of development of education in the world is characterized by a special intensity of transformations, equally affecting the organizational and managerial structures of education, its targets and content, methods and technologies of teaching, sources and mechanisms of financing, as well as the conditions and forms of educational, scientific and industrial cooperation.

In modern conditions, the main priority of the state, first of all, in order to maintain and develop the viability and well-being of the people, should be the development of socio-economic processes, the effective performance of the social function. Public-private partnership is not only economic, but also a very important social significance, plays a decisive role in ensuring a particular standard of living of the country's population, in the formation and development of professional opportunities (Isakhova, 2015).

The goal of developing public-private partnership is:

- firstly, the interaction between the state and business;

- secondly, attracting private investment;

- third, stable economic development;

- fourthly, increasing the competitiveness of the national economy;

- fifth, the formation of a single capital market for goods and services, labor resources.

The process of public-private partnership in general is a specific form of relations between the state and private entrepreneurship, used to solve specific problems, which is currently in an active form of demand. In this regard, from a theoretical and practical point of view, it is of particular interest to analyze the formation and development trends of public-private partnership.

Despite the experience of implementing concession projects, one of the main problems hindering the development of PPP in Kazakhstan is the lack of qualified personnel. In addition, the legislation of the republic does not allow to fully implement the concession models used throughout the world. This makes it difficult to attract investment in the social sphere, housing and communal services and other sectors of the economy.

\section{Literature review}

In many developed and developing countries, public-private partnership is one of the main organizational and economic mechanisms for enhancing innovative activity and attracting long-term investments. PPP as a tool for enhancing and developing innovative activity is widely used by developed countries and has proven its effectiveness in practice.

The literature presents a wide range of studies in the field of PPP and its role in the development of an innovative economy:

- concept and theory by Ablaev I.M., Akhmetshina E.R. (2016),

- methodology by Javed A.A., Lam P.T., Chan A.P. (2014),

- models of interaction between government and business structures in the framework of PPP by Cruz C. O., Marques R.C. (2014),

- approaches to assessing its effectiveness by Berezin A., Sergi B.S., Gorodnova N. (2018).

Authors as Cong X., Ma L. (2018) had considered comparative analysis of international experience in implementing PPP projects. Nevertheless such questions had been considered in the scientific works of Akintoye A., Beck M., Kumaraswamy M. (2016), Roumboutsos A. (2015), Ullah F., Ayub B., Siddiqui S.Q., Thaheem M.J. (2016). 


\section{ENTREPRENEURSHIP AND SUSTAINABILITY ISSUES}

ISSN 2345-0282 (online) http://jssidoi.org/jesi/

2020 Volume 8 Number 2 (December)

http://doi.org/10.9770/jesi.2020.8.2(69)

Make your research more visible, join the Twitter account of ENTREPRENEURSHIP AND SUSTAINABILITY ISSUES: @Entrepr69728810

As international experience shows, studies of Shmelev S. E., Sagiyeva R. K., Kadyrkhanova Z. M., Chzhan Y. Y., Shmeleva I. S. (2018), the implementation of PPP projects is also a way to improve the efficiency of public sector management.

Public-private partnership in the innovation sector allows solving a number of problems of PPP development and has the following advantages:

- provides a great return on research funding, and business entities are interested in the successful solution of issues of further commercialization of their results;

- helps to attract the experience of the private sector and create a competitive environment for open and transparent tenders in the implementation of innovative projects;

- distributes responsibility between partners: the state sets the goals of the project in terms of public interests, determines the cost and quality of parameters, monitors the implementation of projects, and the private partner takes over operational activities at different stages of the project - development, financing, construction and operation, management, practical implementation of services and products.

The study of the aspects of public-private partnership allows us to analyze the mobility of labor resources, since without a mobile labor market, our country is unlikely to be able to quickly solve the issues of modernization and ensuring the innovative orientation of its economy, which would allow it to take its rightful place, in particular, to enter the top twenty competitive countries of the world.

The transfer of new technologies, production and management experience, the replenishment of knowledge and skills, as well as other positive changes in social reproduction are associated with the mobility of the population.

The solution of the entire range of economic and social problems of the development of public-private partnerships requires consistent and steady development and increased efficiency of interaction between the state and business. Thus, E.B. Domolatov, I.N. Dubina, A.N. Turginbayeva (2018) consider in their publications the importance of public-private partnership (PPP) for sustainable growth and increasing the competitiveness of the national economy, and also determine the constraining factors for the development of cooperation in the field of public-private partnership and the use of its mechanisms in the development of innovative investment processes in the economy of Kazakhstan.

On the one hand, the complication of socio-economic life makes it difficult for the state to perform socially significant functions. On the other hand, business is interested in new investment objects (Efimov, 2017). An important role in the implementation of this task is assigned to the economic analysis of the activities of business entities, with the help of which the strategy and tactics of enterprise development are developed, plans and management decisions are justified, their implementation is monitored, reserves for increasing production efficiency are identified, the results of the enterprise, its divisions, employees are evaluated ... Labor resources are the first productive force of social production, and labor productivity is the determining criterion for the socioeconomic development of society as a whole.

The public sector of the economy is important in the life of society. This is due to the fact that the scope of providing important social services, such as health care, social protection and education, largely determines the level of human capital development. As you know, human capital largely determines the potential of the economy and creates important conditions for its development. Thus, the public sector of the economy largely determines the development prospects of the state. In this regard, the use of effective and proven organizational technologies that can significantly improve the quality of services provided in the public sector of the economy is vital. 


\section{ENTREPRENEURSHIP AND SUSTAINABILITY ISSUES}

ISSN 2345-0282 (online) http://jssidoi.org/jesi/

2020 Volume 8 Number 2 (December)

http://doi.org/10.9770/jesi.2020.8.2(69)

Make your research more visible, join the Twitter account of ENTREPRENEURSHIP AND SUSTAINABILITY ISSUES: @Entrepr69728810

In world practice, public-private partnership has established itself as an effective mechanism for optimizing budget expenditures, which allows you to successfully solve important problems of a public nature by attracting private financial and intellectual (human) capital (Shlafman, 2013).

Improving the use of human potential is the main source of social and economic growth. Hence, the importance of collective study and analysis of the main factors that determine both the formation of the composition of labor resources, their professional structure and qualifications, the level of general and special training, and ways to increase labor efficiency. The solution to these problems is possible on the basis of mutually beneficial cooperation in the form of public-private partnership.

Bogdashkina I.V., Kuspanova A.E. (2018) examining the problems of employment, they describe in their publications that effective employment of the working-age population cannot be ensured without purposeful efforts by the state for redistribution, training and social support and protection of citizens. However, these efforts must be consistent with the freedom of activity of the subjects of market relations, meet the requirements of the labor market. Meanwhile Dmitriev Yu. (2015) believes that employers, who are extremely dissatisfied with the state "efforts" in the field of personnel training, also do not show high activity in the area of personnel training.

Analyzing the strategies for improving the quality of the labor force Menshikova M.A., Abbas A.B. (2017) argue that the new economic conditions require serious changes in the structure and characteristics of the labor force by creating a strategy to improve its quality.

According to M. Simonova (2018), improving the quality of the workforce is a systemic task, in the solution of which various states, economic, social, legal, and economic structures should be involved, and their constructive interaction should ensure the required level of quality. The need of post-industrial production for workers who are able not only to meet the requirements, but also to initiate subsequent development, should create conditions for the formation of just such qualities of the human personality.

In the future, the consolidation of the resources of business, the state and the education sector in the development of the system of not only secondary vocational education, but also higher vocational education is possible on the basis of mutually beneficial cooperation in the form of public-private partnership (hereinafter - PPP). In conditions of tight budgets, both regional and republican, public-private partnership is becoming a tool that allows you to implement various projects with minimal state participation.

Studying the foreign experience of public-private partnership, Shadrintseva A.N. (2015) notes that in the world practice there are two types of cluster creation:

1 The first approach provides that at the state level sectoral and regional priorities and the clusters that are planned to be developed are selected (in countries with stronger state regulation of the economy (France, Korea, Singapore, Sweden, Finland, Slovenia, etc.). public authorities purposefully create infrastructure for priority clusters, as well as determine the amount of funding, while funding for these activities can also be supported from the federal budget, including through the implementation of measures of state support for small and medium-sized businesses.

2 In the second approach (used in countries pursuing liberal economic policies (USA, UK, Australia, Canada, etc.), the initiative to create clusters comes from the economic entities themselves operating in market conditions, and government bodies are extremely rarely involved in creating infrastructure and financing the creation of clusters, however, they create a system of incentives for the interest of regional authorities, which are responsible for the effectiveness of the functioning of the created cluster (Shadrintseva, 2015). 


\section{ENTREPRENEURSHIP AND SUSTAINABILITY ISSUES}

ISSN 2345-0282 (online) http://jssidoi.org/jesi/

2020 Volume 8 Number 2 (December)

http://doi.org/10.9770/jesi.2020.8.2(69)

Make your research more visible, join the Twitter account of ENTREPRENEURSHIP AND SUSTAINABILITY ISSUES: @Entrepr69728810

The effective use of labor potential is one of the most important tasks of the formation of a socially oriented state, carried out within the framework of state policy in Kazakhstan.

The labor market as a multifaceted, heterogeneous, dynamic system of socio-economic relations is designed to ensure the constant reproduction and efficient use of labor. With the development of scientific, technical, technological and informational progress, the role of the labor market increases. Therefore, the creation of a balanced labor market in order to replenish the growing sectors of the economy with highly qualified personnel becomes necessary in modern conditions, especially in the interaction of the state and business.

The effective use of labor potential is one of the most important tasks of the formation of a socially oriented state, carried out within the framework of state policy in Kazakhstan, in this connection, the labor market as a multifaceted, heterogeneous, dynamic system of socio-economic relations is designed to ensure constant reproduction and effective use of labor.

With the development of scientific, technical, technological and informational progress, the role of the labor market increases. Therefore, the creation of a balanced labor market in order to replenish the growing sectors of the economy with highly qualified personnel becomes necessary in modern conditions, especially in the interaction of the state and business.

In her scientific publications, Chagina E.A. (2017) considers the labor market as an economic system, where it is necessary to take into account that the socio-infrastructural characteristics of a particular territory determine the degree of closeness of local labor markets. The level and quality of development of the social sphere and engineering infrastructure of the region and territory plays a key role for the development of labor mobility as the most important qualitative indicator of its market value, confirming the integrity of the basic elements of the labor market - labor prices, supply and demand.

In the system of economic relations, labor resources occupy an important place, since labor resources are one of the indicators, the state of which makes it possible to judge national well-being, stability and efficiency of socioeconomic transformations. Some authors, such as P.E. Schlender, Yu.P. Kokin (2019), believe that labor resources are a category that occupies an intermediate position between the economic categories "labor potential" and "total labor force". They note that labor resources are the able-bodied part of the population, which, having physical or intellectual capabilities, is able to produce material goods and provide services.

For example, V.B. Bychin, V.N. Bobkov (2017) argues that "labor resources are part of the country's population capable of participating in the national economy at a given level of development of productive forces and within the framework of these production relations".

According to I.I. Eliseeva (2018), "labor resources are a part of the population with the necessary physical and intellectual abilities and knowledge to work in any area". From this definition, it means that labor resources include both real workers who are already employed in the country's economy and potential workers who are not employed but can work.

Volgin Yu., Odegova Yu.G. (2018) believe that "labor resources represent the working-age population of working age, as well as the resulting set of socio-economic relations at all phases of social production". 
Make your research more visible, join the Twitter account of ENTREPRENEURSHIP AND SUSTAINABILITY ISSUES: @Entrepr69728810

A.L. Mazin (2017) notes that "labor resources are a collection of people with the ability to work, along with many others. When analyzing them, the task is set to investigate a certain category of the population with all its inherent abilities and needs, and above all for work".

\section{Research questions}

Ensuring the rational use of labor resources in all regions of the country is one of the most important tasks of the socio-economic development of the economic complex of Kazakhstan. To solve it, an objective assessment of the labor resources that society has, the needs of the economic complex in the labor force and the ways of the most efficient and complete use of labor resources in the country and regions, based on the interests of the whole society on the basis of public-private partnership are required (Figure 1).

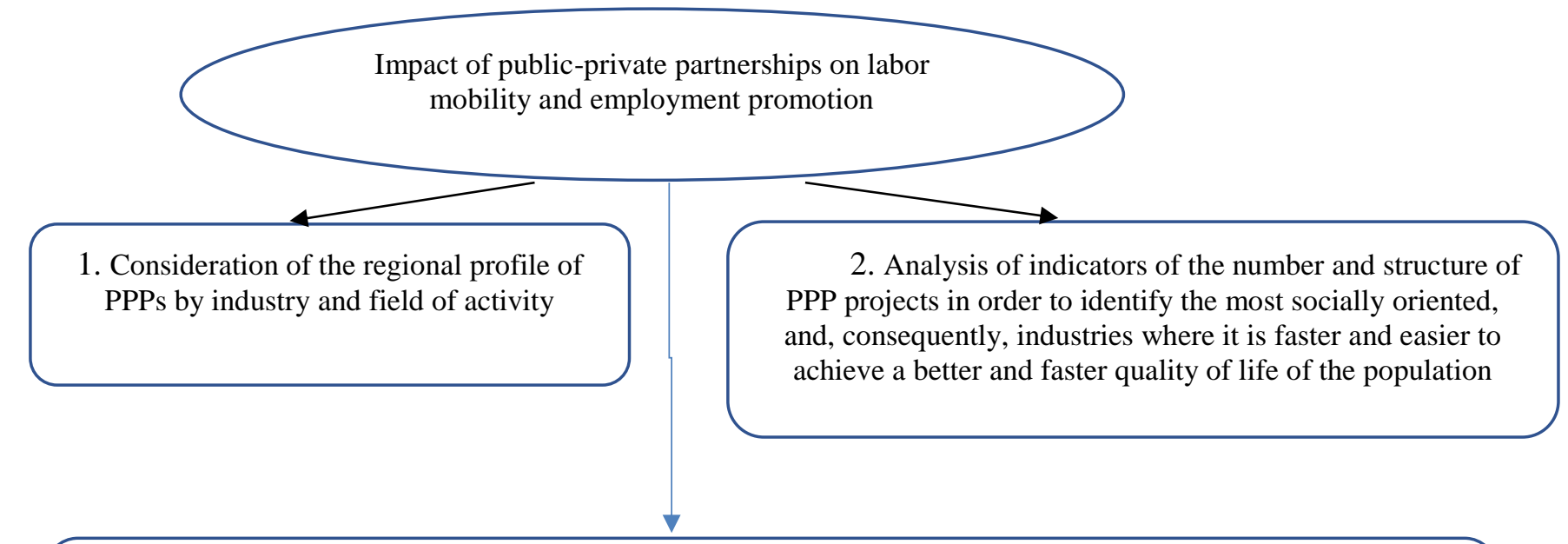

3. Research of aspects of public-private partnership in relation to labor mobility, the state and effective use of which directly affects the final results of the socio-economic development of the state

4. Analysis of the influence of various factors on the unemployment rate in the Republic of Kazakhstan using the method of analysis of variance, as a result of which conclusions and recommendations were made regarding the further development of the institution of public-private partnership in the Republic of Kazakhstan

\section{Figure 1. Research questions}

Source: compiled by authors

The implementation of socially significant projects using public-private partnership mechanisms is to maximize the potential of business and the participation of competent government policy. Optimal provision of the economy as a whole and individual enterprises with employees of the relevant specialties with sufficient qualifications is necessary for the successful functioning and development of enterprises on the basis of public-private partnerships. 
Make your research more visible, join the Twitter account of ENTREPRENEURSHIP AND SUSTAINABILITY ISSUES: @Entrepr69728810

All over the world, PPP schemes are very often used in connection with the construction of healthcare facilities, education, in the field of transport and road transport infrastructure, during the reconstruction and construction of sports facilities. The popularity of PPPs in these areas is explained by a number of advantages for infrastructure projects as a whole: minimization of the project budget, the best price-quality ratio attractive to private investors, the use of the best management and construction technologies, and reduction of commercial risks due to the participation of the state in the project.

\section{Materials and methods}

The majority of projects on the territory of Kazakhstan are in the spheres of education and healthcare. In the field of education, this is the implementation of projects for such objects as kindergartens, schools, dormitories for students and teachers, etc., in the health sector - hospitals, clinics, medical laboratories, feldsher-obstetric centers, etc. Regional profile PPPs by industries and spheres of activity at the end of 2019 are presented in Table 1, where the numerator is the number of projects, and the denominator is the share of the region in a particular industry in $\%$.

Table 1. Regional PPP profile by industries and spheres of activity (2019)

\begin{tabular}{|c|c|c|c|c|c|c|c|c|}
\hline Regions & Utilities & $\begin{array}{l}\text { Health } \\
\text { care }\end{array}$ & $\begin{array}{c}\text { Agriculture, } \\
\text { forestry, } \\
\text { fisheries }\end{array}$ & $\begin{array}{c}\text { Culture, } \\
\text { sports, } \\
\text { tourism, } \\
\text { information } \\
\text { space }\end{array}$ & $\begin{array}{c}\text { Transport and } \\
\text { communications }\end{array}$ & Education & $\begin{array}{l}\text { Other } \\
\text { industries }\end{array}$ & Total \\
\hline $\begin{array}{l}\text { East } \\
\text { Kazakhstan }\end{array}$ & $3 / 1$ & $5 / 2$ & - & $2 / 1$ & $6 / 3$ & $205 / 92$ & $2 / 1$ & $223 / 100$ \\
\hline Almaty city & $2 / 3$ & $3 / 5$ & $11 / 19$ & $5 / 8$ & $7 / 12$ & $31 / 53$ & - & $59 / 100$ \\
\hline Kostanay & $8 / 13$ & $17 / 28$ & $1 / 1$ & $6 / 10$ & - & $26 / 43$ & $3 / 5$ & $61 / 100$ \\
\hline Akmola & $6 / 11$ & $4 / 8$ & $1 / 2$ & - & $2 / 4$ & $40 / 75$ & - & $53 / 100$ \\
\hline Karaganda & $6 / 6$ & $51 / 49$ & $3 / 3$ & $14 / 13$ & $4 / 4$ & $24 / 23$ & $2 / 2$ & $104 / 100$ \\
\hline Kyzylorda & $18 / 16$ & $40 / 35$ & $1 / 1$ & $34 / 30$ & $7 / 6$ & $11 / 9$ & $4 / 3$ & $115 / 100$ \\
\hline Turkestan & $20 / 14$ & $31 / 21$ & - & $8 / 6$ & $1 / 1$ & $66 / 46$ & $17 / 12$ & $143 / 100$ \\
\hline Pavlodar & $13 / 19$ & $23 / 33$ & - & $6 / 9$ & $1 / 1$ & $15 / 21$ & $12 / 17$ & $70 / 100$ \\
\hline Aktuibinsk & $3 / 7$ & $20 / 44$ & $1 / 2$ & $8 / 17$ & $5 / 11$ & $7 / 15$ & $2 / 4$ & $46 / 100$ \\
\hline Almaty & $10 / 24$ & $5 / 12$ & $7 / 17$ & $8 / 19$ & $3 / 7$ & $5 / 12$ & $4 / 9$ & $42 / 100$ \\
\hline $\begin{array}{l}\text { Shymkent } \\
\text { city }\end{array}$ & $18 / 58$ & $5 / 16$ & - & $4 / 13$ & $1 / 3$ & $2 / 7$ & $1 / 3$ & $31 / 100$ \\
\hline Mangistau & $3 / 12$ & $4 / 16$ & - & $1 / 4$ & $1 / 4$ & $13 / 52$ & $3 / 12$ & $25 / 100$ \\
\hline $\begin{array}{l}\text { Nur-Sultan } \\
\text { city }\end{array}$ & $1 / 2$ & $8 / 17$ & $2 / 4$ & $3 / 7$ & $9 / 20$ & $20 / 43$ & $3 / 7$ & $46 / 100$ \\
\hline $\begin{array}{l}\text { North } \\
\text { Kazakhstan }\end{array}$ & $2 / 4$ & $8 / 14$ & - & $4 / 7$ & $2 / 4$ & $38 / 69$ & $1 / 2$ & $55 / 100$ \\
\hline $\begin{array}{l}\text { West } \\
\text { Kazakhstan }\end{array}$ & $1 / 8$ & $5 / 38$ & - & $1 / 8$ & $1 / 8$ & $3 / 23$ & $2 / 15$ & $13 / 100$ \\
\hline Atyrau & $6 / 17$ & $5 / 14$ & $1 / 3$ & $2 / 5$ & $1 / 3$ & $21 / 58$ & - & $36 / 100$ \\
\hline Zhambyl & $1 / 1$ & $31 / 27$ & - & $3 / 3$ & - & $78 / 69$ & - & $113 / 100$ \\
\hline
\end{tabular}

Source: compiled by authors according to the source Committee on Statistics of the Ministry of National Economy of the Republic of Kazakhstan

Most of the projects are being implemented in East Kazakhstan (18\%), Turkestan (12\%), Kyzylorda (9\%), Zhambyl (9\%) regions; least of all - in West Kazakhstan region (1\%), Mangistau region (2\%), Shymkent city (3\%), Atyrau region $(3 \%)$. 


\section{ENTREPRENEURSHIP AND SUSTAINABILITY ISSUES}

ISSN 2345-0282 (online) http://jssidoi.org/jesi/

2020 Volume 8 Number 2 (December)

http://doi.org/10.9770/jesi.2020.8.2(69)

Make your research more visible, join the Twitter account of ENTREPRENEURSHIP AND SUSTAINABILITY ISSUES: @Entrepr69728810

It follows from the above data that there are regions leading in the total number of projects, but projects there are not being implemented in all sectors. The most diversified sectoral structure of PPP is in Kyzylorda, Karaganda, Aktobe, Almaty regions and in the city of Nur-Sultan. All over the world, PPP schemes are very often used in connection with the construction of healthcare facilities, education, in the field of transport and road transport infrastructure, during the reconstruction and construction of sports facilities. The popularity of PPPs in these areas is explained by a number of advantages for infrastructure projects as a whole: minimization of the project budget, the best price-quality ratio attractive to private investors, the use of the best management and construction technologies, and reduction of commercial risks due to the participation of the state in the project.

Also, private financial initiative in PPP projects for the business sector is becoming more common: as of December 31, 2019, 717 PPP contracts were concluded, of which 324 contracts were concluded by private initiative, which is $45 \%$. The average amount of contracts (even if we remove the largest project - BAKAD) from the list, initiated by the state - is 2 billion tenge, while business initiates an average of 1 billion tenge. The amount of state obligations: GI - 362 billion tenge, PFI - 188 billion tenge, and this is a difference of $93 \%$, with a quantitative difference of almost 50\%. 235 new projects worth 156 billion tenge were concluded in Kazakhstan using the practice of publicprivate partnerships in 2019 alone.

In total, as of the end of 2019, 717 PPP agreements were concluded for a total amount of 1.6 trillion tenge, including 9 republican agreements for the amount of 910 billion tenge; 708 - local in the amount of 687 billion tenge (Figure 2). The sole shareholder of Kazakhstan JSC Public-Private Partnership Center is the Government of the Republic of Kazakhstan represented by the Ministry of National Economy of the Republic of Kazakhstan, whose mission is to create conditions for partnership between the state and business, develop and combine their potential for implementing PPP projects and increasing the volume of private investments in the country's economy.

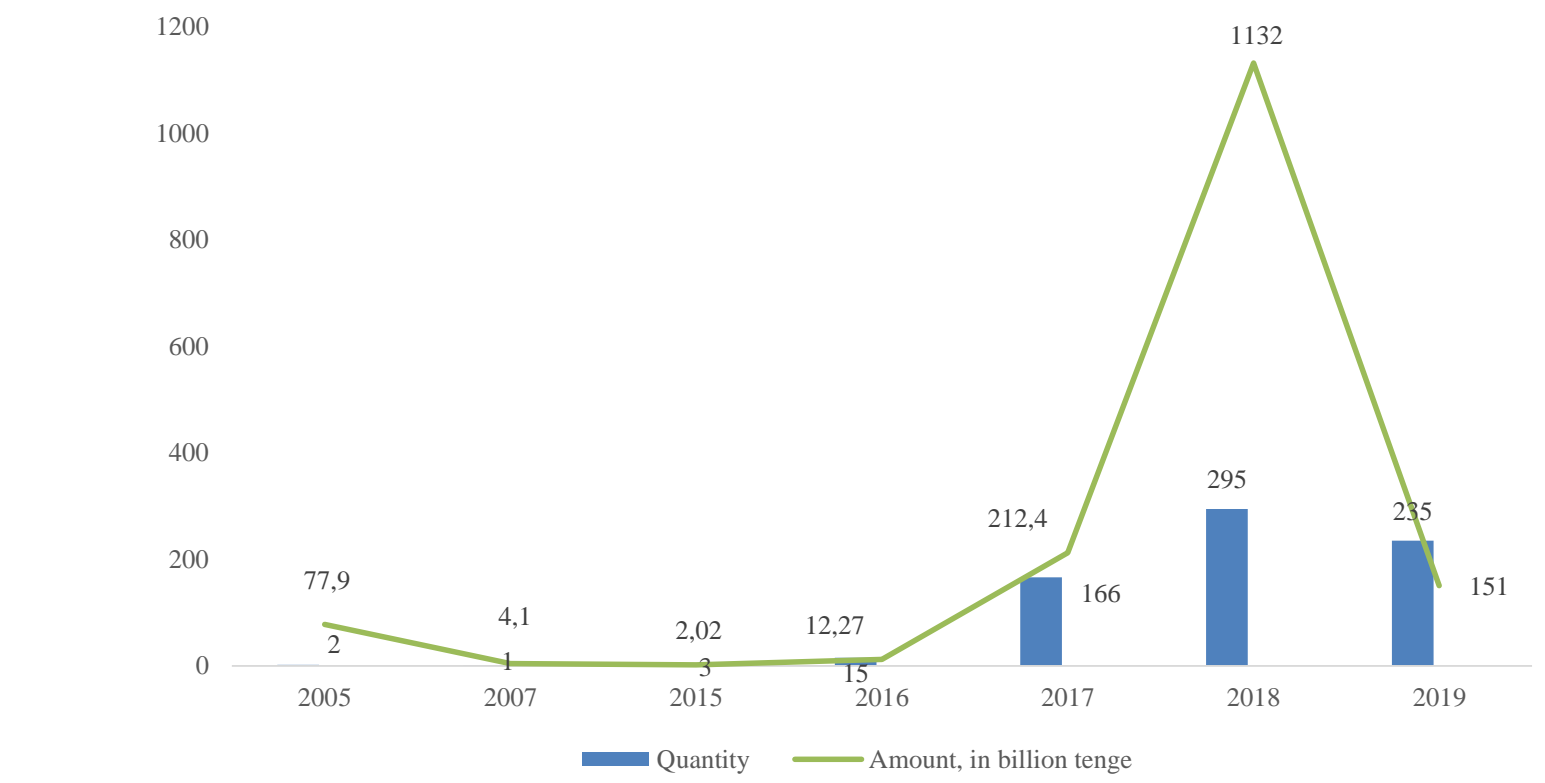

Figure 2. PPP Agreements in the Republic of Kazakhstan for the period from 2005-2019

Source: compiled by authors according to the source Committee on Statistics of the Ministry of National Economy of the Republic of Kazakhstan 
Make your research more visible, join the Twitter account of ENTREPRENEURSHIP AND SUSTAINABILITY ISSUES: @Entrepr69728810

According to statistics from the Ministry of National Economy of the Republic of Kazakhstan, an estimated 8.7 million people were employed in the economy of the republic in July 2019. Among the employed population, the number of employees in the indicated period amounted to 6.6 million people $(76.1 \%$ of the total number of employed). According to preliminary data of the second quarter of 2019, the share of productively employed people out of the total number of self-employed population was $90.3 \%$, unproductively employed $-9.7 \%$. For comparison, the indicators of the labor market of the Republic of Kazakhstan for the period from 2015-2019 were considered (Table 2) (Official site of Committee on Statistics).

Table 2. Main indicators of the labor market of the Republic of Kazakhstan

\begin{tabular}{|c|c|c|c|c|c|}
\hline Indicators & 2015 & 2016 & 2017 & 2018 & 2019 \\
\hline Labor force, thousand people & 8962,0 & 8887,6 & 8998,8 & 9027,4 & 9169,5 \\
\hline Employed population, thousand people & 8510,1 & 8433,3 & 8553,4 & 8585,2 & 8727,9 \\
\hline Employees, thousand people & 6109,7 & 6294,9 & 6342,8 & 6485,9 & 6612,0 \\
\hline Self-employed, thousand people & 2400,4 & 2138,4 & 2210,5 & 2099,2 & 2115,9 \\
\hline Unemployed population, thousand people & 451,9 & 454,2 & 445,5 & 442,3 & 441,6 \\
\hline Unemployment rate, $\%$ & 5,0 & 5,1 & 5,0 & 4,9 & 4,8 \\
\hline Youth unemployment rate, $\%$ (aged 15-24) & 3,8 & 4,2 & 3,8 & 3,8 & 3,7 \\
\hline Youth unemployment rate, $\%$ (aged 15-28) & 4,2 & 4,4 & 4,1 & 3,9 & 3,9 \\
\hline Long-term unemployment rate, $\%$ & 2,4 & 2,5 & 2,2 & 2,2 & 2,2 \\
\hline Persons outside the labor force, thousand people & 3715,9 & 3867,4 & 3855,0 & 3927,3 & 3857,4 \\
\hline
\end{tabular}

Source: compiled by authors according to the source Committee on Statistics of the Ministry of National Economy of the Republic of Kazakhstan

In the structure of the employed population, significant differences persist between urban and rural areas. Thus, $84 \%$ of the urban population are hired workers, the remaining $16 \%$ are self-employed. In rural areas, the share of hired workers is only $61 \%$, and the share of self-employed workers is $39 \%$ (Table 3 ).

Table 3. Analysis of labor resources by employment status in 2019 (thousands of people)

\begin{tabular}{|c|c|c|c|}
\hline Indicators & In urban areas & In the countryside & $\begin{array}{l}\text { In general for the } \\
\text { Republic of } \\
\text { Kazakhstan }\end{array}$ \\
\hline Employed population & 4890,7 & 3662,7 & 8553,4 \\
\hline Employees, including: & 4102 & 2240,9 & 6342,8 \\
\hline - at enterprises and organizations & 3728,5 & 1952,9 & 5681,4 \\
\hline - for individuals & 367 & 174,7 & 541,6 \\
\hline - in a peasant (farm) economy & ,9 & 174,7 & 117,9 \\
\hline Self-employed workers, incl. & 788,7 & 1421,8 & 2210,5 \\
\hline - employers & 59,2 & 59,4 & 118,7 \\
\hline - independent workers & 726,4 & 859 & 2080,9 \\
\hline - members of the cooperative & 0,2 & 0,9 & 1,1 \\
\hline - helping (unpaid) workers in family businesses & 2,9 & 6,9 & 9,8 \\
\hline
\end{tabular}

Source: compiled by authors according to the source Committee on Statistics of the Ministry of National Economy of the Republic of Kazakhstan 
Make your research more visible, join the Twitter account of ENTREPRENEURSHIP AND SUSTAINABILITY ISSUES: @Entrepr69728810

Let's analyze the influence of various factors on the unemployment rate in the Republic of Kazakhstan. For this we will use the method of analysis of variance.

First, let's analyze the impact on the unemployment rate of the place of residence (city or countryside). The required data are presented in Figure 3.

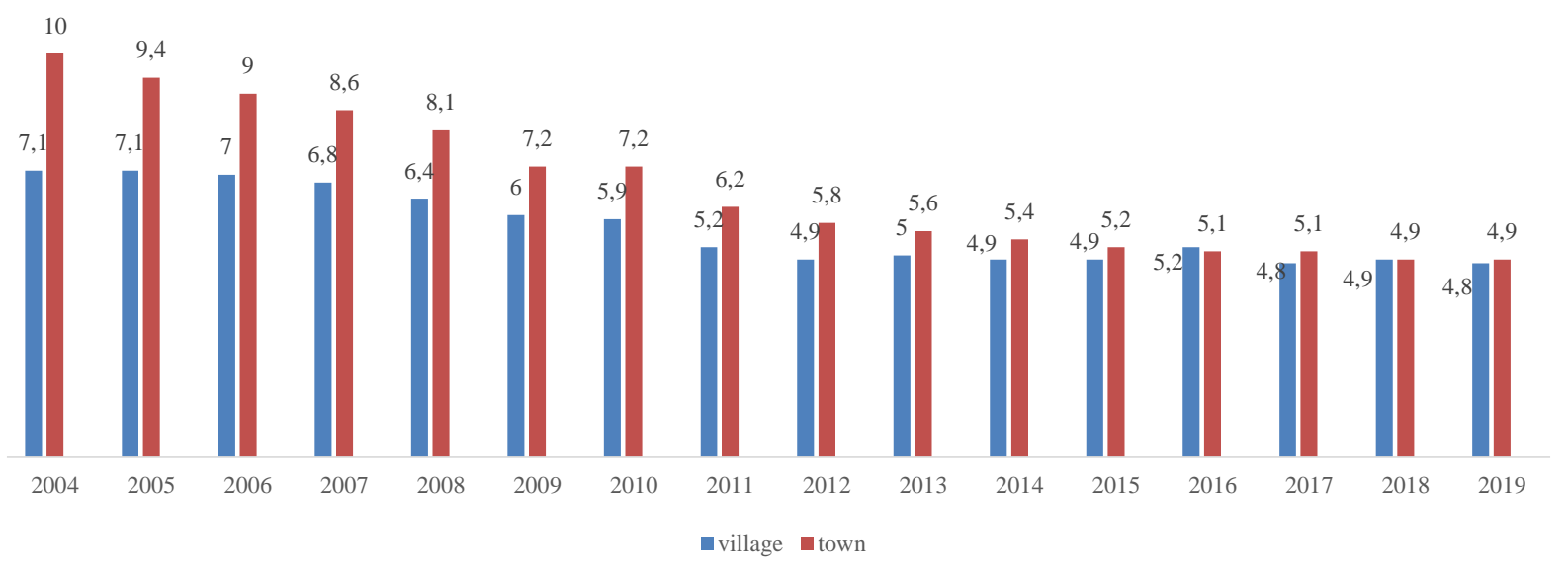

Figure 3. Dynamics of the unemployment rate in the Republic of Kazakhstan depending on the place of residence, in \% Source: compiled by authors according to the source Committee on Statistics of the Ministry of National Economy of the Republic of Kazakhstan

Statistics show that the urban unemployment rate is on average $1.05 \%$ higher than in rural areas.

Let us put forward and verify with the help of analysis of variance, a hypothesis about the influence of place of residence on the unemployment rate. Using statistical data, it was found that the factorial variance is $s_{\text {fact. }}^{2}=8,820$ , residual variance $-s_{\text {res. }}^{2}=1,998$. So that $s_{\text {fact }}^{2}>s_{\text {res. }}^{2}$, then, in accordance with the considered method, it follows at the significance level $\alpha=0,05$ check the significance of their differences. To do this, we calculate the observed value of the F-criterion:

$$
F_{\text {observ. }}=\frac{s_{\text {fact. }}^{2}}{s_{\text {res. }}^{2}}=\frac{8,820}{1,998}=4,414 .
$$

The critical value of the Fischer-Snedecor test at the significance level $\alpha=0,05$ and the number of degrees of freedom $k_{1}=1, \quad k_{2}=30$ equally $F_{\text {crit. }}(0,05 ; 1 ; 30)=4,171$.

As $F_{\text {observ. }}>F_{\text {crit. }}$, therefore, at the significance level $\alpha=0,05$ a conclusion should be drawn about the influence of the place of residence on the unemployment rate.

Let us analyze the influence of gender and age on the unemployment rate in the Republic of Kazakhstan, for this we apply a two-factor analysis of variance. The required data are presented in Figure 4. 
Make your research more visible, join the Twitter account of ENTREPRENEURSHIP AND SUSTAINABILITY ISSUES: @Entrepr69728810

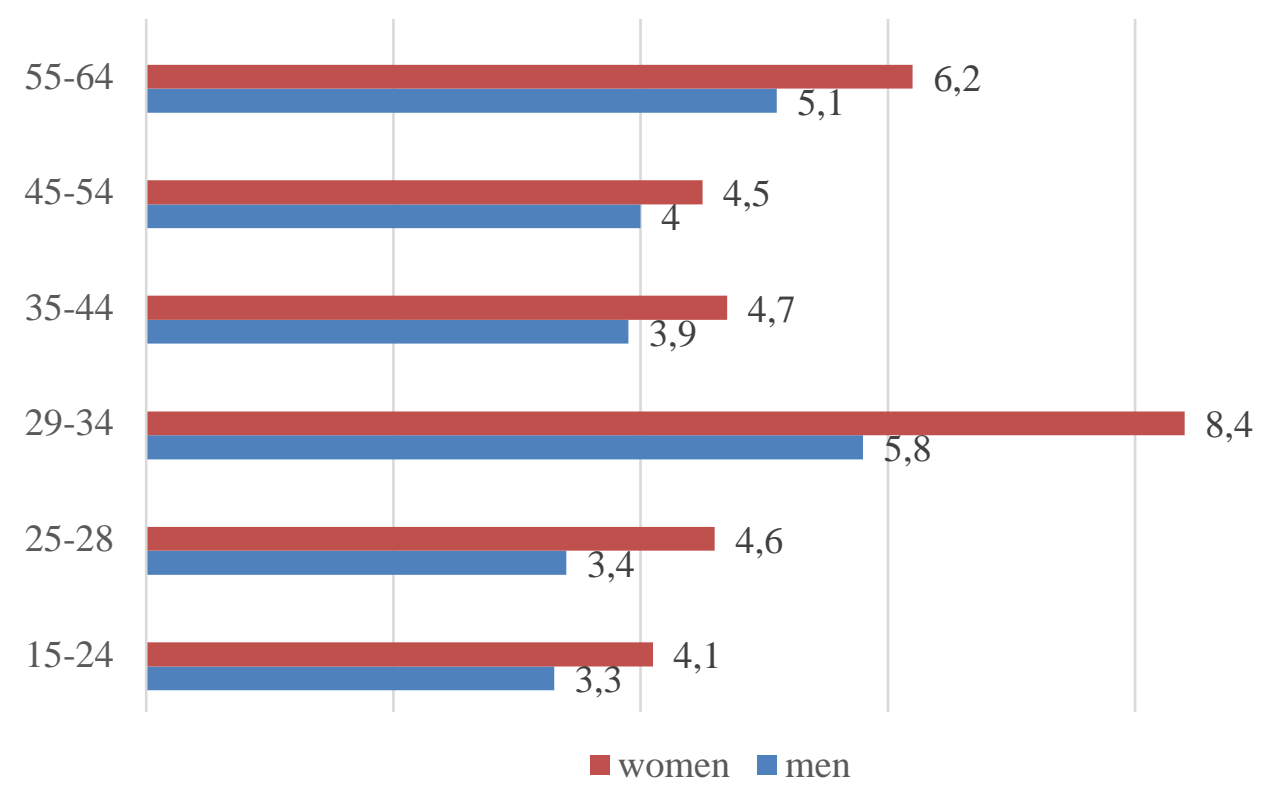

Figure 4. Unemployment rate in the Republic of Kazakhstan depending on age and gender for 2019, in \% Source: compiled by authors according to the source Committee on Statistics of the Ministry of National Economy of the Republic of Kazakhstan

Thus, we see that the highest unemployment rate is observed in the age group from 29 to 34 years old. The unemployment rate for women in every age group is higher than for men, with an average difference of $1.17 \%$.

Let us put forward and test, using two-way analysis of variance, a hypothesis about the influence of gender and age on the unemployment rate. Using the statistical data, we will carry out the necessary calculations. As a result, the following results were obtained:

- factor variance by factor «age»: $s_{\text {age }}^{2}=3,363$,

- factor variance by factor «gender»: $s_{\text {gen }}^{2}=4,083$,

- residual variance: $s_{\text {res }}^{2}=0,277$.

Let's compare the obtained values: $s_{\text {age }}^{2}>s_{\text {res }}^{2}, s_{\text {gen }}^{2}>s_{\text {res }}^{2}$. Since both found factor variances exceed the residual, in accordance with the ANOVA rule, it is necessary to calculate the observed values of the F-test:

$$
F_{\text {obs }}^{(\text {age })}=\frac{s_{\text {age }}^{2}}{s_{\text {obs }}^{2}}=\frac{3,363}{0,277}=12,141, F_{\text {observ }}^{(\text {gender })}=\frac{s_{\text {gender }}^{2}}{s_{\text {obs. }}^{2}}=\frac{4,083}{0,277}=14,740 .
$$

Critical values of the Fischer-Snedecor distribution at the significance level $\alpha=0,05$ and the number of degrees of freedom for the factor «age» $k_{1}=5, k_{2}=5$, for factor «gender» $k_{1}=1, k_{2}=5$ equal to $F_{\text {crit }}^{\text {(age) }}(0,05 ; 5 ; 5)=5,050, F_{\text {crit. }}^{\text {(gender) }}(0,05 ; 1 ; 5)=6,607$. 
Make your research more visible, join the Twitter account of ENTREPRENEURSHIP AND SUSTAINABILITY ISSUES: @Entrepr69728810

As $F_{\text {obs }}^{(\text {age })}>F_{\text {crit }}^{(\text {age })}$, a $F_{\text {obs. }}^{(\text {gender })}>F_{\text {crit. }}^{(\text {gender })}$, then at the significance level $\alpha=0,05$ it should be concluded that both factors «gender» and «age» have a significant impact on the unemployment rate.

Thus, using analysis of variance, we proved that all the factors considered: "place of residence", "gender" and "age" affect the unemployment rate. First of all, it should be noted that there is gender inequality in Kazakhstan, the unemployment rate among women is higher. In addition, unemployment is subject to age differentiation. The largest percentage of unemployed is observed in the age groups from 29 to 34 years old and from 55 to 64 years old. In the latter case, this is due to the pre-retirement age. Also, the percentage of unemployed population in the city is higher than in the countryside. In the context of a significant outflow of the economically active population from the countryside to the city, not only the pressure on the urban labor market is increasing, but also significant changes are taking place in the social structure of the countryside, the deepening of social differentiation and transformation of rural society.

It should be especially noted that the preservation of the category of unproductively self-employed is a factor in increasing the economic burden on the country's budget system.

Regionally, $46 \%$ of the self-employed population is located in the Southern region, namely:

- Almaty $(12.67 \%)$

- Zhambyl (10.22\%),

- South Kazakhstan (22.74\%)

- Kyzylorda (5.5\%).

The rest of the self-employed population is located:

- North $(21.58 \%)$,

- Western $(10.27 \%)$

- East $(9.09 \%)$

- Central (3.31\%).

The development of self-employment is driven by both economic and social factors. On the whole, a positive downward trend in the number of the self-employed population remains against the background of an increase in the number of employees.

In 2019, the rate of coverage of the economically active population (hereinafter - EAP) of the country with higher education is higher than 2004 by $9.6 \%$. A significant increase was recorded in 2018 (Figure 5).

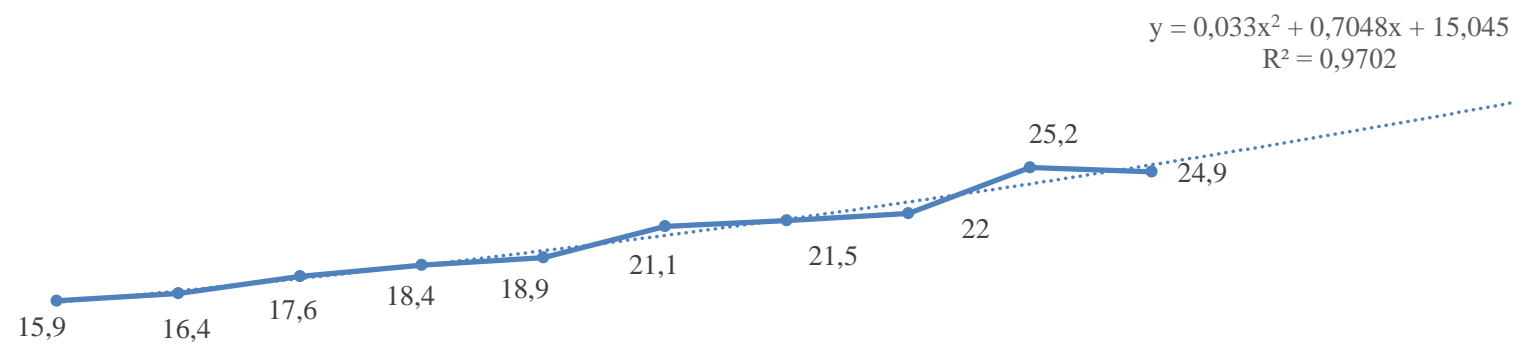

$\begin{array}{llllllllll}2010 & 2011 & 2012 & 2013 & 2014 & 2015 & 2016 & 2017 & 2018 & 2019\end{array}$

Figure 5. Share of the EAP of the Republic of Kazakhstan with higher education, in \%

Source: compiled by authors according to the source Committee on Statistics of the Ministry of National Economy of the Republic of Kazakhstan 
Make your research more visible, join the Twitter account of ENTREPRENEURSHIP AND SUSTAINABILITY ISSUES: @Entrepr69728810

The quality of qualified personnel depends, of course, on the quality of higher education, which stakeholders interpret in different ways:

1. The State Program for the Development of Education and Science prioritizes training, employment and positioning of Kazakhstan universities in the QS WUR international ranking. This ranking focuses on academic reputation, taking into account the survey of experts, employer ratings, faculty / student ratio, the number of international students and faculty, and the citation index. National accreditation agencies in the quality assurance standards of the university also include effective strategic planning, management and information management, student orientation, quality of educational programs, teaching staff, research work, resources, public information, periodic external quality assurance (Standards for Institutional Accreditation).

2. GIK WEF optimally determines the quality of the educational system as consistency between educational programs, graduates' end results and the needs of the labor market. Kazakhstan took the overall 56th place in the fifth direction of the GIK 2018-2019 "Higher education and vocational training" focus on educational coverage, the quality of mathematical and natural science training of applicants, management schools and the possibility of continuing education on the job.

Table 4 shows a comparative analysis in the context of regions in terms of such indicators as the age structure, the proportion of young specialists, the number of IEPs who have undergone advanced training (Nurlanov, Amankazy, Nogaybaeva, 2018).

Table 4. Comparative analysis by regions of the Republic of Kazakhstan

\begin{tabular}{|c|c|c|c|c|}
\hline \multirow[t]{2}{*}{ Region } & \multirow[t]{2}{*}{$\begin{array}{c}\text { Share of IPR, age } \\
\text { structure, in \% }\end{array}$} & \multicolumn{2}{|c|}{$\begin{array}{l}\text { Number of IPRs who have completed } \\
\text { advanced training courses, people }\end{array}$} & \multirow{2}{*}{$\begin{array}{c}\text { Share of young } \\
\text { professionals in the TVE } \\
\text { system, in } \%\end{array}$} \\
\hline & & $\begin{array}{c}\text { Number of managers, } \\
\text { people }\end{array}$ & $\begin{array}{c}\text { Number of IPR, } \\
\text { people }\end{array}$ & \\
\hline Akmola & 8,7 & 18 & 280 & 8,8 \\
\hline Aktuibinsk & 5 & 16 & 250 & 10 \\
\hline Almaty & 9,5 & 26 & 400 & 8,7 \\
\hline Atyrau & 11,4 & 12 & 200 & 11,5 \\
\hline West Kazakhstan & 6,6 & 18 & 210 & 7,8 \\
\hline Zhambyl & 4 & 18 & 310 & 8,3 \\
\hline Karaganda & 7 & 31 & 480 & 8,9 \\
\hline Kostanay & 8,5 & 22 & 280 & 7,5 \\
\hline Kyzylorda & 5,6 & 11 & 240 & 8,9 \\
\hline Mangistau & 10 & 9 & 140 & 10 \\
\hline South Kazakhstan & 5,9 & 28 & 560 & 9,2 \\
\hline Pavlodar & 10,2 & 22 & 300 & 13,8 \\
\hline North Kazakhstan & 8,4 & 14 & 180 & 5,6 \\
\hline East Kazakhstan & 11,3 & 32 & 360 & 8 \\
\hline Astana city & 8,3 & 8 & 260 & 11,4 \\
\hline Almaty city & 10,7 & 15 & 450 & 16,6 \\
\hline
\end{tabular}

According to the data in Table 4, in the context of regions, it can be seen that an increase in the share of IRP of retirement age takes place almost everywhere. A significant increase in this indicator is observed in the East Kazakhstan region and in Almaty. At the same time, there is a decrease in this indicator in Atyrau and Kyzylorda regions. In terms of types of economic activity, the largest number of job vacancies is:

-in industry - 8,599 units;

- in the field of transport and storage - 3,999 units;

- the smallest - in transactions with real estate - 197 units (Table 5). 
Make your research more visible, join the Twitter account of ENTREPRENEURSHIP AND SUSTAINABILITY ISSUES: @Entrepr69728810

Table 5. Vacant jobs and expected need for workers by economic activity and type of ownership as of 2019 in Kazakhstan

\begin{tabular}{|c|c|c|c|c|}
\hline \multirow{2}{*}{ Indicator } & \multirow{2}{*}{$\begin{array}{l}\text { Number of vacancies at the } \\
\text { beginning of the reporting } \\
\text { period, units }\end{array}$} & \multicolumn{3}{|c|}{ including } \\
\hline & & state property & private property & foreign property \\
\hline Total & 28305 & 1538 & 8458 & 1243 \\
\hline $\begin{array}{l}\text { Agriculture, forestry and } \\
\text { fisheries }\end{array}$ & 399 & - & - & - \\
\hline Industry & 8599 & 76 & 2360 & 414 \\
\hline Construction & 1830 & - & 1694 & - \\
\hline $\begin{array}{l}\text { Wholesale and retail trade; } \\
\text { repair of cars and } \\
\text { motorcycles }\end{array}$ & 2090 & $\mathrm{x}$ & 802 & $\mathrm{x}$ \\
\hline Transport and storage & 3999 & $\mathrm{x}$ & $\mathrm{x}$ & 15 \\
\hline $\begin{array}{l}\text { Accommodation and food } \\
\text { services }\end{array}$ & 453 & - & 112 & 69 \\
\hline $\begin{array}{ll}\text { Information } & \text { and } \\
\text { communication } & \\
\end{array}$ & 1091 & - & 140 & 101 \\
\hline Real estate operations & 197 & $\mathrm{x}$ & 155 & $\mathrm{x}$ \\
\hline $\begin{array}{l}\text { Professional, scientific } \\
\text { and technical activities }\end{array}$ & 1099 & 54 & 101 & 123 \\
\hline $\begin{array}{ll}\text { Administrative } & \text { support } \\
\text { activities } & \\
\end{array}$ & 1716 & $\mathrm{x}$ & 625 & $\mathrm{x}$ \\
\hline Education & 1394 & 373 & 117 & - \\
\hline $\begin{array}{l}\text { Healthcare and social } \\
\text { services }\end{array}$ & 4526 & 744 & $\mathrm{x}$ & $\mathrm{x}$ \\
\hline $\begin{array}{l}\text { Arts, entertainment and } \\
\text { recreation }\end{array}$ & 912 & 76 & $\mathrm{x}$ & $\mathrm{x}$ \\
\hline
\end{tabular}

Source: compiled by authors

The highest expected staffing requirements are noted:

- in industry (2 850 people);

- in construction (1,694 people);

- in the field of art, entertainment and recreation (1 239 people);

- in the sphere of wholesale and retail trade, car and motorcycle repair (1,199 people) and the share of these types of economic activities in the total expected need for workers was $62.1 \%$.

At enterprises and organizations with private ownership, the expected need for workers in 2019 was 8,458 people, of which:

- in industry - 2,360 people;

- in construction - 1,694 people;

- in the sphere of wholesale and retail trade, car and motorcycle repair - 802 people.

At enterprises and organizations with a state form of ownership, the greatest need falls on the sphere of health care and social services (744 people). Their share in the total expected demand for workers at state-owned enterprises was $48.4 \%$.

According to the Project "Productive Employment", the improvement of the quality of education and, accordingly, the training of qualified personnel must be carried out through:

1. Modernization of educational programs:

- development of innovative educational programs, including the training of IT specialists with competencies in cybersecurity, web design, promotion in social networks; 
Make your research more visible, join the Twitter account of ENTREPRENEURSHIP AND SUSTAINABILITY ISSUES: @Entrepr69728810

- implementation of minor programs in priority sectors (for example, an educational program in the agro-industrial complex + trade) + maintaining the current state order for industries where there is an outflow of personnel;

- expanding the activities of universities in the implementation of short-term training courses;

- staff mobility (including student mobility, since the attraction of foreign students today is perceived as one of the important indicators of the competitiveness of higher education. This phenomenon is called internationalization of higher education) (Gaidarova, Ashimkhanova, 2016).

2. Development of dual learning.

3. Development of lease financing instruments and the creation of specialized competence centers, laboratories and classrooms of the "new format".

4. Systemic measures to organize the training of qualified personnel, taking into account the new structure of employment:

- restructuring the volume of the state order for training personnel with higher education and vocational education (Program of productive employment and mass entrepreneurship, project Free TVE) for the service economy, taking into account the new structure of employment (Law of the RK, 2018);

- increasing the attractiveness of training courses for blue-collar occupations by introducing an educational Internet platform, digital educational resources.

So, for example, within the framework of the Project "With a Diploma to the Village!" since 2009, measures have been taken to provide social support for specialists in education, health care, social security, culture and sports, and the agro-industrial complex who have arrived to work and live in rural areas (Figure 6) (Program of the President, 2015).

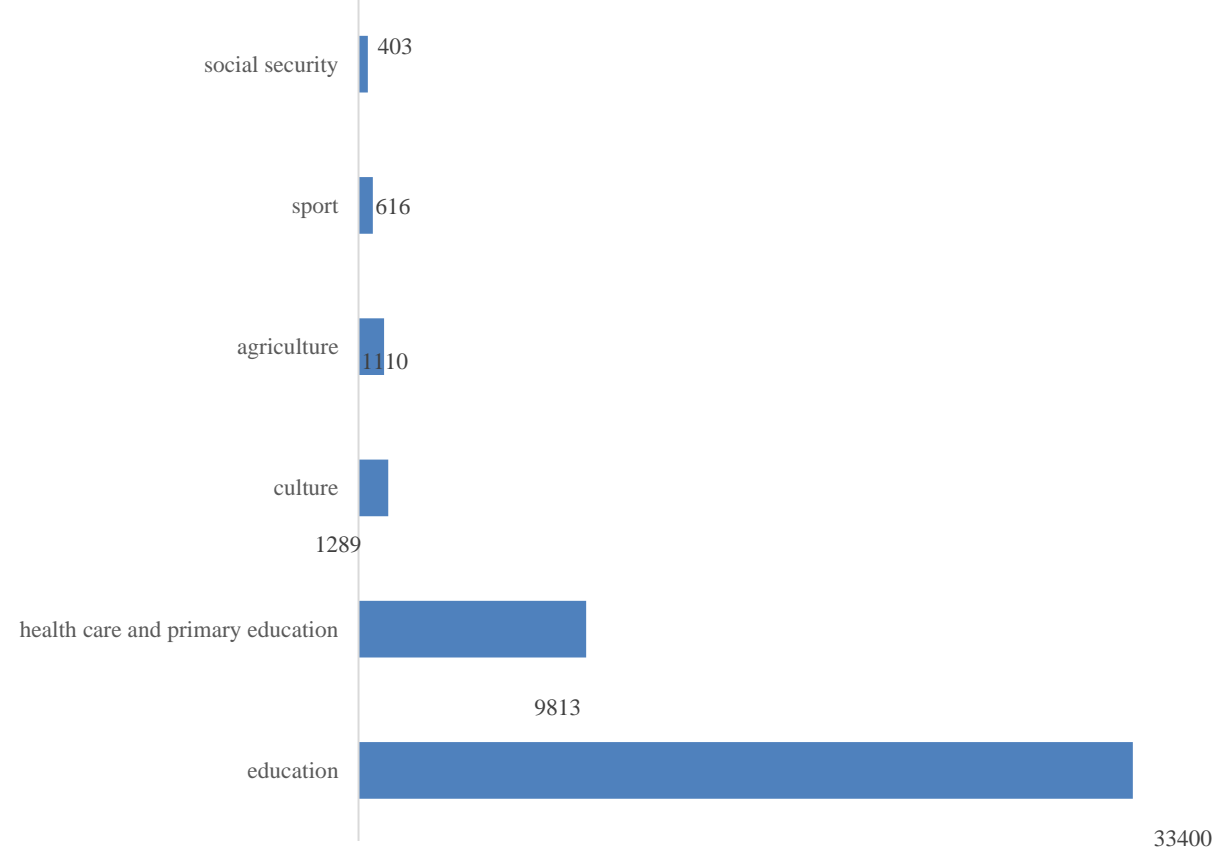

Figure 6. Dynamics of arrived specialists in Kazakhstan under the project "With a diploma in the village!" in the context of industries Source: compiled by authors 


\section{ENTREPRENEURSHIP AND SUSTAINABILITY ISSUES}

ISSN 2345-0282 (online) http://jssidoi.org/jesi/

2020 Volume 8 Number 2 (December)

http://doi.org/10.9770/jesi.2020.8.2(69)

Make your research more visible, join the Twitter account of ENTREPRENEURSHIP AND SUSTAINABILITY ISSUES: @Entrepr69728810

For such specialists, it was provided:

- payment of a one-time lifting allowance in the amount of $70 \mathrm{MCI}$;

- a budget loan in the amount of 1,500 MCI for the purchase or construction of housing for a period of 15 years, with a remuneration rate of $0.01 \%$;

- an increase by at least $25 \%$ of official salaries (tariff rates) for specialists of social institutions located in rural areas.

We would like to note that in 2018, the amendments to the Law of the Republic of Kazakhstan "On migration of the population" established an integral system for regulating the resettlement of citizens. In order to eliminate the disparities in the settlement of the population, it was envisaged to provide economic incentives for the voluntary resettlement of the population from labor-surplus regions to regions with a high potential for the development of the labor market, reception of migrants, with the provision of measures of state support and assistance in employment (Law of the RK, 2018).

Thus, the stable development of the socio-economic situation in the country is facilitated by the mobility of labor resources as one of the main solutions for the optimal use of labor resources in regions with a shortage of labor by moving them from labor-surplus areas. This enables individuals to find a better job offer. Labor resources are one of the most important factors in any production. Their condition and effective use directly affects the final results of the socio-economic development of the state (Berglund, 2017).

\section{Conclusions}

The problem of developing the public services sector through the introduction of public-private partnership mechanisms is an urgent task.

In the modern sense, PPP is an institutional and organizational alliance between the state and business in order to implement national and international, large-scale and local, but always socially significant projects in a wide range of areas of activity: from the development of strategically important industries and research and development (R\&D) before providing public services.

For the development of public-private partnerships and the implementation of projects similar to the above in the regions of Kazakhstan, it is necessary to create favorable conditions for the formation of this institution. Among the main factors hindering the widespread use of PPP mechanisms in the economy of Kazakhstan are the following reasons:

1) insufficiently developed regulatory and legal framework;

2) the absence of mechanisms for effective financing and insurance of projects equally for all market participants, a significant political component for the implementation of long-term projects;

3) ineffectively functioning legal institutions that could guarantee the rights of private owners participating in projects;

4) limited access of potential PPP participants to large projects due to the high requirements imposed on them by the state;

5) low level of diversity and underutilization of the potential of promising forms and instruments of public-private partnership, which significantly limits the possibilities of its use.

Analysis of the current state of public-private partnership in relation to labor mobility and the prospects for its development within the framework of the general strategy of the third modernization allows us to determine the following main goals of regulating these processes.

1. Meeting the needs of the economy in the necessary labor force, subordinating migration to the solution of medium and long-term goals and objectives of the country's socio-economic development.

2. Formation of an optimal system of population settlement in the territory of the Republic of Kazakhstan. 


\section{ENTREPRENEURSHIP AND SUSTAINABILITY ISSUES}

ISSN 2345-0282 (online) http://jssidoi.org/jesi/

2020 Volume 8 Number 2 (December)

http://doi.org/10.9770/jesi.2020.8.2(69)

Make your research more visible, join the Twitter account of ENTREPRENEURSHIP AND SUSTAINABILITY ISSUES: @Entrepr69728810

3. Ensuring the national security of the Republic of Kazakhstan in the context of threats associated with migration. To achieve the set goals, the following tasks will be required:

1. Building an effective system of external labor migration, focused on meeting the needs of the country's economy, creating a favorable investment climate and improving the quality of labor resources.

2. Updating the policy of ethnic migration, taking into account the strategic development plans of Kazakhstan in order to strengthen national consolidation and create favorable adaptation and integration conditions for ethnic repatriates arriving in the Republic of Kazakhstan.

3. Suppression of illegal migration.

4. Creation of an effective internal migration management system for the purpose of economically justified settlement of the population, ensuring regional and demographic balance in the development of the country.

Approaches to the creation of a modern system of public-private partnership in relation to the management of labor mobility require rethinking and further development.

This study confirms the fact that the issue of increasing the development of public-private partnerships in relation to labor mobility should be included in the general labor market policy; to solve it, additional systems of programs and measures should be used. Such programs and measures include passive and active measures that can be combined to stimulate job seekers to make decisions in favor of moving to a new job in a new location.

Consequently, among the main tasks of public-private partnership, it is necessary to highlight:

- "updating the system of legal regulation of employment and labor relations through changes and amendments to labor and social legislation, orientation of people to an independent active position of citizens in the field of employment and guarantees of social protection to the most vulnerable categories of citizens;

- "macroeconomic regulation of the economy, that is, improvement of the sectoral structure of the economy based on the creation of new industries and the reform of promising ones through privatization, reorganization, reprofiling, implementation of financial and tax policies, consistent with an employment policy that supports the creation of additional jobs;

- "support and active stimulation of the development of small and medium-sized businesses that create additional jobs, including by attracting foreign capital;

- "the formation of a system of social partnership of the main participants in the labor market - the state, employers, workers in ensuring employment guarantees, decisions on wages, working conditions and regimes.

Thus, it is necessary to improve the scientific and methodological foundations of public-private partnership, to develop and create conditions for a wider practical application of mechanisms, models of PPP in cities, adopting the advanced experience of developed countries, in the implementation of socially significant projects.

\section{References}

Ablaev, I., Akhmetshina, E. 2016. The role of the public private partnership in the innovation cluster development. Journal of Economics and Economic Education Research, 17 (4), 220-232. https://doi.org/10.14258/201849

Akintoye, A., Beck, M., Kumaraswamy, M. 2016. Public Private Partnerships: A Global Review. Taylor and Francis, 412 p. https://doi.org/10.4324/9781315686516

Berezin, A., Sergi B., Gorodnova, N. 2018. Efficiency assessment of public-private partnership (PPP) projects: The case of Russia. Sustainability, 10 (33), 1-18. https://doi.org/10.3390/su10103713 


\section{ENTREPRENEURSHIP AND SUSTAINABILITY ISSUES}

ISSN 2345-0282 (online) http://jssidoi.org/jesi/

2020 Volume 8 Number 2 (December)

http://doi.org/10.9770/jesi.2020.8.2(69)

Make your research more visible, join the Twitter account of ENTREPRENEURSHIP AND SUSTAINABILITY ISSUES: @Entrepr69728810

Berglund, Th. 2017. Promoting labor mobility in the labor markets of the Republic of Kazakhstan and the Russian Federation. Moscow: Yurait, $93 \mathrm{p}$.

Bogdashkina, I., Kuspanova, A. 2018. Efficiency of state programs in solving problems of employment of the population. Actual problems of our time: science and society, 4(5), 8-14.

Bychin, V. 2017. Labor Economics. Moscow: Infra-M, 336 p.

Chagina, E. 2017. Problems of analysis and evaluation of the effectiveness of programs of territorial mobility of labor resources. Problems of modern economy, 4 (164), 157-159.

Cong, X., Ma, L. 2018. Performance evaluation of public-private partnership projects from the perspective of Efficiency, Economic, Effectiveness, and Equity: A study of residential renovation projects in China. Sustainability, 10(33), 1-21. https://doi.org/10.3390/su10061951

Cruz, C., Marques, R. 2014. Theoretical considerations on quantitative PPP viability analysis. Journal of Management in Engineering, 30 (1), 122-126. https://doi.org/10.1016/S2212-5671(15)00609-7

Dmitriev, Yu. 2015. Improving the quality of the labor force is a necessary condition for economic growth. Bulletin of the Vladimir State University, 1 (3), 111-117.

Domalatov, E., Dubina, I., Turginbayeva, A. 2018. State and development of public-private partnership in the innovation sphere of Kazakhstan: comparison with international practice. Economics, 4 (9), 21-29. https://doi.org/10.14258/ 201849

Efimov, E. 2017. Public - private partnership: problems in the relationship between the state and business. Internet journal "Science", 5(7), 32-39. http://dx.doi.org/10.15862/143EVN515

Eliseeva, I. 2018. Statistics. Moscow: Yurait, 565 p.

Gaidarova, N., Ashimkhanova, D. 2016. National report "Youth of Kazakhstan - 2016". Astana, 201p.

Isakhova, P. 2015. Public-private partnership in Kazakhstan as a tool for the development of investment activities. Bulletin of MIEP, 1 (18), 64-67.

Javed, A., Lam, P., Chan, A. 2014. Change negotiation in public-private partnership projects through output specifications: an experimental approach based on game theory. Construction Management and Economics, 32(4), 323-348. https://doi.org/10.1080/01446193.2014.895846

Law of the Republic of Kazakhstan "On migration of the population". 2018. Retrieved from: https://www.zakon.kz/

Mazin, A. 2017. Labor Economics. Moscow: UNITI-DANA, 575 p.

Menshikova, M., Abbas, A. 2017. Analysis of strategies for improving the quality of labor force. Auditorium, 2 (12), 89-96.

Nurlanov, E., Amankazy, M., Nogaybaeva, M. A. 2018. National report “On the state of development of the education system of the Republic of Kazakhstan”. Astana: JSC IAC. 434 p.

Official site of the Committee on Statistics of the Ministry of National Economy of the Republic of Kazakhstan. http://www.stat.gov.kz

Program of the President of the Republic of Kazakhstan. 2015. "Plan of the nation - 100 concrete steps". Retrieved from: https://www.zakon.kz/.

Roumboutsos, A. 2015. Public Private Partnerships in Transport Infrastructure: An International Review. Transport Reviews, 35(2), 111117. https://doi.org/10.1080/01441647.2015.1017025

Shadrintseva, A. 2015. Development of the institution of public-private partnership in the field of improving the quality of labor and promoting employment of the population. Bulletin of SGUGiT, 3(31), 122-128. 
Make your research more visible, join the Twitter account of ENTREPRENEURSHIP AND SUSTAINABILITY ISSUES: @Entrepr69728810

Shlafman, A. 2013. Genesis of the integration processes in economy of the Russian Federation: problems of cyclicity and state regulation. Scientific and technical Bulletin of St. Petersburg state Polytechnic University, 1(185), 39-47.

Shlender, P. 2019. Labor economics. Moscow: Yurait, 686 p.

Shmelev, S., Sagiyeva R., Kadyrkhanova, Z., Chzhan, Y., Shmeleva, I. 2018. Comparative sustainability analysis of two Asian cities: A multidimensional assessment of Taipei and Almaty. The Journal of Asian Finance, Economics and Business, 5(3), 143-155. http://doi.org/10.13106/jafeb.2018.vol5.no3.143.

Simonova, M. 2018. Improving the quality of the workforce is the basis of personnel development. Development of the institution of a reserve of managerial personnel in the constituent entities of the Russian Federation as a challenge of the time and an effective tool for improving state personnel policy, Samara, Working papers, 8(19), 224-229.

Standards for Institutional Accreditation of Higher Education Organizations. 2017. IQAA

Statistical collections of Global Labor Market Trends. 2018. Human Resource Development Center.

Ullah, F., Ayub, B., Siddiqui, S., Thaheem, M. 2016. A review of public-private partnership: critical factors of concession period. Journal of Financial Management of Property and Construction, 21 (3), 269-300. https://doi.org/10.1108/JFMPC-02-2016-0011

Volgin, Yu. 2018. Labor Economics: Social and Labor Relations. Moscow: UNITI-DANA, 736 p.

Raikhan NURANOVA is PhD student of Narxoz University, Almaty, Kazakhstan. Research interests: labour, lbour market, economic development, macroeconomics.

ORCID ID: orcid.org/0000-0002-5321-1165

Maira RYSKULOVA is Candidate of Economic Sciences, Professor of of Narxoz University, Almaty, Kazakhstan. Research interests: finance, macroeconomics, innovation, strategic planning.

ORCID ID: orcid.org/0000-0002-1944-5339

Kulyash AIDARKHANOVA is Candidate of law, Associate professor of Al-Farabi Kazakh National University, Almaty, Kazakhstan. Research interests: economics, entrepreneurship regulation, innovation.

ORCID ID: orcid.org/0000-0002-6392-4708

Nurgul BAIGELOVA is Candidate of law, Associate Professor of the Kazakh University of Narxoz University, Almaty, Kazakhstan. Research interests: labour, lbour market, economic development, macroeconomics.

ORCID ID: orcid.org/0000-0001-5163-7077

Copyright (C) 2020 by author(s) and VsI Entrepreneurship and Sustainability Center This work is licensed under the Creative Commons Attribution International License (CC BY). http://creativecommons.org/licenses/by/4.0/ 